\title{
İnternet-media resurslarının qiymətləndirilməsində veb-statistika mexanizmlərinin rolu
}

\author{
Rasim Oliquliyev ${ }^{1}$, Səadət Abdullayeva ${ }^{2}$, \\ ${ }^{1,2}$ İnformasiya Texnologiyaları İnstitutu, Bakı, Azərbaycan \\ ${ }^{1}$ directorlit.science.az, ${ }^{2}$ seadet.agayeva@gmail.com
}

\begin{abstract}
Xülasə- Məqalədə İnternet-media resurslarının qiymətləndirilməsi vasitələri araşdırılmış, bu sahədə vebstatistika alətlərindən istifadənin üstünlükləri analiz olunmuşdur. Həmçinin İnternet-medianın qiymətləndirilməsi zamanı təhlükəsizlik məsələlərinə baxılmış və bir sıra təkliflər irəli surülmüşdür.
\end{abstract}

Açar sözlor- veb-satistika, veb-analitika, media, monitorinq, medianın qiymotlondirilmosi, təhlükəsizlik

\section{GIRIS}

İnformasiya cəmiyyəti quruculuğu şəraitində formalaşan müasir media bir sıra yeni keyfiyyət xüsusiyyətləri əldə edib. Müasir dövrdə medianın tendensiyalarından biri də İnternetmediadır. Kütləvi informasiya vasitələrinin yeni növünün çox sürətli inkişafı bu fenomenin elmi-nəzəri cəhətdən dərk edilməsi zərurətini yaratmışdır. İnternet-medianın yaradıcılıq imkanları ilə yanaşı, onun texnoloji inkişafının öyrənilməsi Internet-medianın qiymətləndirilməsinin aktual və praktik əhəmiyyətli istiqamətlərindəndir.

\section{II. İNTERNET-MEDIANIN QIYMӘTLONDIRILMOSI VASITӘLӘRI}

İnformasiya-kommunikasiya texnologiyalarının geniş vüsət alması ilə ortaya çıxan İnternet-media istifadəçilərin zaman və məkandan asılı olmayaraq interaktiv ünsiyyətdə olduqları bir media vasitəsidir. Internet-media resurslarının effektivliyinə nəzarət etmək üçün onların monitorinqinin aparılması və qiymətləndirilməsi müasir dövrdə getdikcə artan əhəmiyyətə malikdir.

Monitorinq məlumat mənbələrinin müəyyən edilməsi və onlar üzərində müşahidə, məlumatların toplanması və saxlanılması, kateqoriyalaşdırma və filtrləmə yolu ilə ən uyğun məlumatların seçilməsi və toplanmış məlumatların təhlilini özündə birləşdirir [1, 2]. Real vaxt rejimində media qurumu monitorinq və qiymətləndirmə aparmaqla veb-saytda yaranmış problemlərin geniş yayılmasının qarşısını ala, ona vaxtında reaksiya verə bilər. Belə analiz saytın geriləməsi barədə məlumatların əldə olunmasına imkan verir, baş verə biləcək böhranları aşkar edir. Bununla saytın digər media saytları ilə müqayisədə reputasiyanın gücləndirilməsi üçün imkanlar müəyyən edilə bilər [3].

İnternet-medianın monitorinqi və qiymətləndirilməsi [1]:

- $\quad$ problem və onların səbəblərini müəyyən etməyəkömək edir;

- $\quad$ problemlərin mümkün həll yollarını müəyyən edir;

- $\quad$ şirkətin fəaliyyət istiqamətlərini müəyyən etməyə vəbu istiqamətlərə təsir etməyə imkan verir;

- informasiya siyasətinin düzgün qurulmasına kömək edir və s.

İnternet-medianın idarə edilməsi özündə media qurumu haqqinda mövcud olan fikirləri rəqəmsal platformalar vasitəsilə anlamaq və buna uyğun olaraq qərarlar qəbul etmək üçün alətlərdən istifadəni ehtiva edir. İnternet-medianın qiymətləndirilməsi üçün veb-analitika vasitələrindən geniş istifadə olunur. Veb-analitika veb-saytların keyfiyyətinin yüksəldilməsi və optimallaşdırılması üçün istifadəçilər haqqında informasiyanın toplanması, ölçülməsi, tədqiqi, təsviri və interpretasiyasıdır.

Veb-analitika erası 1990-c1 ildə HTTP protokolunun yaranması ilə başlandı. 1995-ci il iyun ayında Stiven Turner tərəfindən "Analog" pulsuz veb loq analizi proqramı yaradıldı və bu proqram saytların server jurnallarının ilk analizatoru funksiyasını yerinə yetirdi [4]. Veb-analitika aşağıdakı məsələlərin həllində geniş tətbiq olunur:

- Veb-saytın qarşıya qoyulmuş hədəflərə uyğun olubolmadığının müəyyənləşdirilməsi;

- Trafikin kəmiyyət və keyfiyyət göstəricilərinin qiymətləndirilməsi;

- On səmərəli trafik mənbələrinin müəyyənləşdirilməsi;

- Veb-saytın strukturu, naviqasiyası və məzmununda problemli tərəflərin aşkarlanması;

- Veb-sayta müraciətlərin sayına əsasən funksionallığın artırılması.

Veb-analitika veb-sayt, onun sosial şəbəkələri və mobil marketinqi daxil olmaqla şirkətin rəqəmsal marketinq platformaları diapazonunda olan kommunikasiya kampaniyalarının effektivliyinin artırılması və istehlakçılarla 


\section{"İnformasiya tohlükosizliyinin aktual problemlori" \\ III respublika elmi-praktiki seminart, 08 dekabr 2017-ci il}

qarşılıqlı təsir məsələlərinin həllində mühüm əhəmiyyət kəsb edir [5]. İnternet-marketinqin əsasını təşkil edən veb-analitika media qurumlarının marketinq strategiyasının proqnozlaşdırılması, bazarın təhlil olunması, istifadəçilərin sayta münasibətinin monitorinqinin aparılması və s. baxımdan vacibdir. İnternet-medianın fəaliyyətinin təkmilləşdirilməsi üçün lazım olan məlumatların hesablanmasını həyata keçirən veb-analitikada veb-saytların zəif tərəflərinin aşkara çıxarılması məqsədilə veb-statistika alətlərindən istifadə edilir.

\section{III. İNTERNET-MEDIA RESURSLARININ QIYMӘTLӘNDIRILMӘSINDə VEB-STATISTIKA ALӘTLӘRINDЭN ISTIFADӘ}

Veb-statistikanın aparılması veb-resursun effektivliyinin monitorinqi və qiymətləndirilməsinə, onun işinin yaxşılaşdırılmasına, veb-sayta müraciətlərin sayının artırılmasına və s. imkan verir. İnternet-media resurslarının qiymətləndirilməsi məqsədilə veb-statistika alətlərindən istifadə olunması veb-saytın informasiya siyasətinin düzgün qurulmasında mühüm rol oynayır. Məsələn, 1993-cü ildə ildə ABŞ-da yaradılmış "WebTrends" şirkəti veb, sosial, mobil analitika və proqram təminatı ilə bağlı bir sıra rəqəmsal marketinq problemlərinin həlli ilə məşğul olmuşdur. Şirkət tərəfindən veb-statistika alətlərindən istifadə olunması veb-sayt rəhbərləri və marketoloqların bu sahəyə böyük marağına səbəb olmuşdur [6].

İnternet-media resursunun veb-statistikası aşağıdakı məsələlərin həlli məqsədilə aparıla bilər:

- Saytın İnternet mühitində müəyyənləşdirilməsi;

- Hədəf auditoriyasının öyrənilməsi;

- Saytın iqtisadi siyasətinin müəyyənləşdirilməsi;

- Veb-saytın istifadəçilərinin coğrafiyasının müəyyənləşdirilməsi (ölkədaxili, ölkəxarici) və müqayisəsi;

- İstifadəçilərin sosial təsnifatı (kişi, qadın);

- Saytın dil auditoriyasının müəyyənləşdirilməsi;

- Saytda yerləşdirilən gündəlik informasiyanın həcminin müəyyənləşdirilməsi;

- Sayta müraciət edən istifadəçilərin zaman üzrə aktivliyinin öyrənilməsi;

- Ohalinin hansı informasiyaya istiqamətlənməsinin analizi və $\mathrm{s}$.

Veb-statistika əsasında istənilən marketinq kampaniyalarını qurmaq, bazarı təhlil etmək, veb-saytın funksional imkanlarını inkişaf etdirmək və genişləndirmək başqa sözlə, ziyarətçilərin saytın daimi auditoriyasına çevrilməsi üçün tədbirlər görmək mümkündür.

Dünyada veb-statistika xidməti göstərən bir çox şirkətlər mövcuddur. $\mathrm{Bu}$ şirkətlərin istifadə etdikləri veb-statistika proqramları İnternet-sayğacların ənənəvi prinsipi - saytın səhifələrində quraşdırılmış kodun sayta müraciətləri qeydə alması və onlar haqqında məlumatları toplaması üzrə işləyir. Bu sistemlər arasında sayta müraciətlərin analizi üçün geniş funksionallığa malik olan "Google Analytics", "Yandeks Metrika”, “Liveİnternet”, "Rambler's Top 100”, “Рейтинг Mail.Ru" sayğaclarından istifadə olunur [7].
Təhlillər göstərir ki, sayğacların köməyi ilə əldə olunmuş informasiya məlumat massivlərini formalaşdıraraq, informasiyanın ayrı-ayrı hissələrini və tematik seçmələri araşdıra və gələcəkdə öz geniş tətbiqini tapa bilər. Bu halda aşağıdakı qiymətləndirmələr aparmağa imkan verən göstəricilər qrupu istifadəo olunur [8]:

\section{Ümumi auditoriyanın qiymotlandirilmasi:}

- Ümumi statistika: ziyarətçilərin və onların nəzər yetirdikləri səhifələrin sayı; yeni ziyarətçilərin sayı; ziyarətçilərin regional bölgüsü; sosio-demoqrafik xarakteristikalar; rəqiblərlə müqayisə;

- Saytın ziyarətçilərinin mənbələri: onların hansı axtarış sistemləri, reklam kampaniyaları və s. vasitəsilə sayta daxil olduğunun müəyyənləşdirilməsi;

- Sayta keçid üçün axtarış sistemində istifadə olunan axtarış ifadələrinin müəyyənləşdirilməsi;

- Sayta müraciətlərin davamiyyət göstəriciləri: veb-saytın hansı bölmələri daha çox müraciət olunandır, sayta baxışlar nə qədərdir, saytda səhifələrə baxış hansı yollar üzrə baş verir və s.

Auditoriyanın keyfiyyatinin qiymatlandirilmasi:

- Hədəf auditoriyası: saytda yeni aktivlik göstərən ziyarətçilərin say1;

- Saytın ziyarətçilərin hansı yollarla sayta daxil olduğunun müəyyənləşdirilməsi.

Hazırda dünyada İnternet-media resurslarının qiymətləndirilməsi üçün ən çox müraciət olunan sayğac "Google Analytics" hesab olunur. Bu proqram veb-saytların ziyarətçilərinin statistikasının hazırlanması üçün "Google" şirkəti tərəfindən təqdim olunan ödənişsiz xidmətdir. Statistik məlumatlar "Google"un serverində toplanır. Lakin bu xidmətin ödənişsiz versiyası aylıq 10 milyondan çox baxış sayı olan saytların analizinə zəmanət vermir. Buna görə də, şirkət 2011-ci il sentyabr ayından etibarən 1 milyard müraciəti olan saytların statistikasının aparılması üçün “Google Analytics Premium”dan istifadəni təklif edir [9].

Qeyd etmək lazımdır ki, bəzi statistika alətləri isə vebserverin loqlarını başqa sözlə, konkret sayta bütün müraciətlərin mətn faylları ilə qeydini təqdim edirlər. Hər qeyd özündə müvəqqəti hədəfi, sorğunun tipi və serverin qisa cavabını saxlayır ki, bununla saytın istifadəçilərinin davranışının kifayət qədər dərin analizini aparmaq imkanı yaranır. 2003-cü ildə yaradılmış "Liveinternet" statistika xidməti və digər bəzi statistik vasitələr bir çox saytlarda öz kodunu yerləşdirir və statistikanın daha geniş mənzərəsini əldə edirlər.

$\mathrm{Bu}$ üsullardan hər biri özünəməxsus xüsusiyyətlərə, üstünlüklərə və çatışmazlıqlara malikdir. Veb-saytların loqları və ya sayğaclarından əldə olunmuş bütün məlumatlar avtomatik formalaşdırılaraq hesabatlar formasında təqdim olunur. $\mathrm{Bu}$ hesabatlara:

- Sayta müraciətlərin dinamikası haqqında hesabatlar;

- Ziyarətçiləri xarakterizə edən, onların coğrafi artımı (ölkə, region, şəhər) haqqında məlumatları özündə ehtiva edən hesabatlar;

- Ziyarətçilərin hansı səhifələrdən daxil olduğunu və saytın ən çox müraciət olunan səhifələri haqqında məlumatları özündə saxlayan hesabatlar; 


\section{"İnformasiya tohlükosizliyinin aktual problemlori" \\ III respublika elmi-praktiki seminart, 08 dekabr 2017-ci il}

- Müraciət edənlərin istifadə etdiyi əməliyyat sistemi, proqram təminat, brauzeri və $\mathrm{s}$. haqqinda hesabatlar daxildir.

Son zamanlar bəzi veb-analitika provayderləri sosial media monitorinq vasitələrini veb-analitika ilə inteqrasiya etməyə başlayıblar. Populyar monitorinq şirkəti "Radian6" vebanalitikanı "Radian6"nın istifadəçi interfeysinə inteqrasiya etmək üçün ilk veb-analitika provayderlərindən biri olan "WebTrends" ilə əməkdaşlıq etməyə başlamışdır. "Radian6"və "WebTrends"in bu inteqrasiyası xüsusi paylaşım və ya sayt tərəfindən nə qədər ziyarətçinin göndərildiyini anlamağa imkan verir [10].

\section{INTERNET-MEDIANIN QIYMӘTLӘNDIRILMOSI ZAMANI TəHLÜKəSIZLIK MəSЭLӘLӘRI}

Hazırda İnternet-media qurumlarının veb-saytlarında təqdim olunan xəbərlərin kontentinə nəzarət olunması vacib məsələlərdəndir. Belə ki, bu materiallarda yer alan məlumatlar bəzən insanların mənəvi-psixoloji sağlamlığına zərər vurmaqla bərabər, ölkənin milli təhlükəsizliyini də təhlükə altında qoya bilər. Şüurun manipulyasiyası, fərqli mənəvi dəyərlərin təbliği, informasiya müharibələri və bu kimi informasiya təhlükələri əslində millətin varlığının əsas dayaqlarından olan millimənəvi dəyərlər sisteminin dağıdılması üçün nəzərdə tutulmuş gizli virus rolunu oynayır [11]. Media qurumları bu tip təhlükələr, onların mənbələri, növləri, törədə biləcəyi fəsadlar barədə məlumatlı olmalı, bu təhlükələrdən qorunma üsulları haqqında bilik və bacarıqlara malik olmalıdırlar ki, təhlükəsizliyi təmin edə bilsinlər. Bunun üçün veb-saytların mütəmadi olaraq qiymətləndirilməsi aparılmalı, zərərli kontentlər aşkar olunmalıdır. İnformasiya ilə işləyən mütəxəssislərin informasiya təhlükəsizliyi sahəsində texniki bilik və bacarıqlarının lazımi səviyyədə olması üçün kadr potensialını gücləndirmək təhlükəsizliklə bağlı problemlərin aradan qaldırılmasına kömək edər.

Bununla yanaşı, media qurumlarının təhlükəsizlik tələbləri və siyasəti, informasiyanın klassifikasiya üsulları müəyyənləşdirilməli, veb-saytın monitorinqi və qiymətləndirilməsinə cavabdeh olan şəxslər dəqiq təyin edilməlidir. Məhz onlar mövcud problemlərin həlli yollarını təklif etməlidirlər. Veb-saytlarda olan boşluqların əvvəlcədən müəyyən olunması istiqamətində işlər görülməli, saytlara avtorizasiyasız girişlər, təhlükəsizliklə bağlı nüanslar klassifikasiya edilməlidir. $\mathrm{Bu}$, təhlükəsizliyin qorunması məsələsində diqqət yetirilməli məqamların müəyyənləşdirilməsinə kömək edə bilər.

Araşdırmalar nəticəsində məlum oldu ki, ölkədə İnternetmedia resurslarının sayı kifayət qədər olsa da, İnternet-media hələ formalaşma mərhələsindədir. Belə ki, milli media qurumlarının veb-saytlarının statistikasının aparılması Azərbaycan dövlətinin strateji maraqlarına cavab vermir. Bu problemlərin həlli üçün Azərbaycanın milli-mənəvi maraqlarına, o cümlədən milli dövlətçilik ənənələrinə cavab verən milli veb-statistika mexanizmləri yaradılmalı, standartlar müəyyən olunmalıdır.

\section{NӘTICӘ}

Araşdırmaların nəticələri göstərir ki, İnternet-medianın fəaliyyətinin veb-statistika alətlərindən istifadə etməklə

mütəmadi olaraq qiymətləndirilməsi və təhlükəsizliklə bağlı qeyd olunan təkliflər nəzərə alınmaqla qurulması veb-saytların müsbət yöndə inkişafını təmin edən əsas amillərdəndir.

İnternet-media qurumlarının veb-saytların statistikasının aparılması bəzi məsələlərin həllinə kömək edir:

- Saytın funksionallığının artırılması;

- Saytın strukturu, kontenti və naviqasiyasında problemli tərəflərin aşkara çıxarılması;

- İnternet-media resursları ilə bağlı mövcud bazarın analizi;

- Hədəf auditoriyasının maraqlarının müəyyənləşdirilməsi və s.

İnternet-media resurslarının qiymətləndirilməsi vasitələrindən istifadə zamanı beynəlxalq təcrübə, texnoloji yeniliklər, inkişaf meylləri nəzərə alınmalı və dövlət prioritetləri əsas götürülməlidir.

\section{ӘDӘBIYYYAT}

[1] Oliquliyev R.M., Ağayeva S.R., "İnternet-media resurslarının monitorinqi: müasir vəziyyəti, problemləri və inkişaf perspektivləri”, İnformasiya cəmiyyəti problemləri, 2016, №1, səh. 63-70

[2] "Media Monitoring Service", http://pages.rediff.com/media-monitoringservice/305165

[3] B. Zhang and M. Vos, "Social media monitoring: methods, benefits and difficulties for international companies", "Corporate Communications: an International Journal”, Vol. 19, No 4, 2014, 371- 383 pp.

[4] А.Кошик, "Веб-аналитика. Анализ информации о посетителях вебсайтов”, 2009, 464 стр.

[5] "Web analytics and social media monitoring", syllabus, CAM Foundation, 2013, 7 p.

[6] "Web analytics, Digital Marketing”, www.webtrends.com

[7] П.В. Скородумов, А.Ю Холодев, “Анализ подходов и инструментальных средств анализа статистики посещения веб-сайта научной организации”, “Вопросы территориального развития”, вып. 9 (29), 2015, 13 стр.

[8] Н.Г. Воскресенская Е.Г. Фирулина, “Медиаметрические исследования целевой аудитории: методика количественного анализа", Учебно-методическое пособие, «Нижегородский государственный университет им. Н.И. Лобачевского» Факультет международных отношений, 2014, 66 стр.

[9] "Google Analytics Premium Service”, Periscopix, 2013, 16 p.

[10] S. Duncan, "Using Web Analytics to Measure the Impact of Earned Online Media on Business Outcomes: A Methodological Approach", San Francisco, California, 2011, 22 p.

[11] R.Mahmudova, "İnformasiya təhlükəsizliyi mədəniyyətinin formalaşdırılması problemləri”, "İnformasiya təhlükəsizliyi problemləri üzrə I respublika elmi-praktiki konfransı", 17-18 may, 2013, səh. 22-25

\section{THE ROLE OF WEB STATISTICS MECHANISMS IN ONLINE MEDIA RESOURCE ASSESSMENT}

\author{
${ }^{1}$ Rasim Alguliyev, ${ }^{2}$ Saadat Abdullayeva \\ ${ }^{1,2}$ Institute of Information Technology of ANAS, Baku, Azerbaijan \\ ${ }^{1}$ director@iit.science.az, ${ }^{2}$ seadet.agayeva@gmail.com
}

Abstract - The article examines tools for evaluating online media resources, analyzes the advantages of using web statistics tools in this area. Also, an information security issues were reviewed while evaluating the online media and a number of suggestions were put forward.

Keywords - web statistics, web analytics, media, monitoring, media evaluation, information security 